\title{
Alternative method of treating prolonged wound defects of trunk and extremities
}

\author{
E. V. Ponomarenko, I. S. Kovalenko \\ Zaporizhzhia State Medical University, Ukraine
}

The aim of the study is to improve the treatment results in patients with prolonged wound defects on the trunk and extremities by using alternative methods.

Materials and methods of research: 75 patients with neurotrophic disorders aged 19-76 years were treated. Of the total number $25(33.3 \%)$ of patients were treated according to the methodology having been developed in the clinic.

Results and discussion: In 25 (33.3\%) cases of a neurotrophic ulcerative defect, skin regeneration course was prescribed for 2 to 6 weeks. We have had positive results (complete defects healing) in all the cases. The clinical experience of using hyaluronic acid preparation has been scientifically substantiated by the complex pathomorphological studies of skin biopsy material (histological, histochemical, immunohistochemical techniques ones using monoclonal antibodies Rb a-Hu Collagen I, Clone RAHC11 and Rb a-Hu Collagen III, Clone RAHC33 (Imtek, Russian Federation) to collagen I and III types).

Conclusions: The choice of corrective intervention method and the closure of the defect depended on the size, depth of the wound and the functional characteristics of the site of the injury. The new method of treatment of neurotrophic ulcers expands the prospects for treatment of patients with defects in the integumentary tissues. At the pathomorphological examination, the signs of healing with hyperproliferative processes were revealed in the epidermis, hyperkeratosis, parakeratosis, and excessive accumulation of collagen type I that characterized pathological healing and was often determined in the epidermis in chronic ulcers. Differential approach to selecting the method of closing wound surfaces makes it possible to achieve positive results in $98.1 \%$ of cases.

\section{Альтернативний спосіб лікування тривало існуючих ранових дефектів тулуба та кінцівок}

\section{О. В. Пономаренко, І. С. Коваленко}

Мета роботи - поліпшити результати лікування хворих із тривало існуючими рановими дефектами тулуба та кінцівок шляхом застосування альтернативних методів.

Матеріали та методи. У клініці проліковано 75 хворих із нейротрофічними розладами віком від 19 до 76 років. 25 (33,3 \%) пацієнтів від загальної кількості проліковано за методикою, котра розроблена в клініці.

Результати. У 25 (33,3 \%) випадках нейротрофічного виразкового дефекту призначений курс редермалізації протягом 2-6 тижнів із позитивним результатом (повне заживлення дефекту) в усіх випадках. Клінічний досвід застосування препарату гіалуронової кислоти науково обґрунтований комплексним патоморфологічним дослідженням біопсійного матеріалу шкіри (гістологічними, гістохімічними, імуногістохімічними методиками з використанням моноклональних антитіл $R b$ a-Hu Collagen I, Clone RAHC11 та Rb a-Hu Collagen III, Clone RAHC33 («Iмтек», Російська Федерація) до колагену I та III типів).

Кнючові слова: рани, виразка, морфологічні та мікроскопічні показники, гіалуронова кислота.

Патологія. - 2017. T. 14, № 2(40). C. 197-201

Висновки. Вибір методу корегуючого втручання та закриття десекту залежав від розмірів, глибини рани та функціональних особливостей ділянки пошкодження. Новий спосіб лікування нейротрофічних виразок розширює перспективи лікування пацієнтів із дефектами покривних тканин. Під час патоморфологічного дослідження виявлялись ознаки загоєння з гіперпроліферативними процесами в епідермісі, гіперкератозом, паракератозом і надмірним накопиченням колагену I типу, що характеризує патологічне загоєння та часто визначається в епідермісі при хронічних виразках. Диференційний підхід до вибору методу закриття ранових поверхонь дає можливість досягнути позитивних результатів у 98,1% випадків.

\section{Альтернативный способ лечения Аиительно существующих раневых дефектов туловища и конечностей}

\section{Е. В. Пономаренко, И. С. Коваленко}

Цель работы - улучшить результаты лечения больных с длительно существующими раневыми дефектами туловища и конечностей путем применения альтернативных методов.

Материалы и методы. В клинике пролечено 75 больных с нейротрофическими трофическими дефектами в возрасте от 19 до 76 лет. 25 (33,3 \%) пациентов от общего количества пролечено по методике, разработанной в клинике.

Результаты. В 25 (33,3 \%) случаях нейротрофических язвенных десектов был назначен курс редермализации в течение 2-6 недель с положительным результатом (полное заживление дефекта) во всех случаях. Клинический опыт применения препарата гиалуроновой кислоты был научно обоснован комплексным патоморфологическим исследованием биопсийного материала кожи (гистологическими, гистохимическими, иммуногистохимическими методиками (с использованием моноклональных антител Rb a-Hu Collagen I, Clone RAHC11 и Rb a-Hu Collagen III, Clone RAHC33 («Имтек», Российская Федерация) к коллагену I и III типов). 
Выводы. Выбор метода корректирующего вмешательства и закрытия дефекта зависел от размеров, глубины раны и функциональных особенностей участка повреждения. Новый способ лечения нейротрофических язв расширяет перспективы лечения пациентов с дефектами покровных тканей. При патоморфологическом исследовании обнаруживались признаки заживления с гиперпролиферативными процессами в эпидермисе, гиперкератозом, паракератозом и чрезмерным накоплением коллагена I типа, что характеризует патологическое заживление и часто определяется в эпидермисе при хронических язвах. Дифференцированный подход к выбору метода закрытия раневых поверхностей позволяет достичь положительных результатов в $98,1 \%$ случаев.

Patients with prolonged wound defects are, first of all, the category of patients with disability for an indefinite period, possible disability and a significant decrease in the quality of life. As a rule, the patients receive long-term courses of treatment in several medical institutions, as outpatients too. The presence of wound surfaces leads to the limitation of physical activity, the need for regular painful dressings, permanent sense of malaise, the onset of drugs' side effects, emotional disorder.

Most often, the causes of prolonged wounds formation are vascular diseases (trophic ulcers in chronic venous insufficiency, ischemic ulcers in obliterating diseases of arteries), complicated forms of diabetes mellitus (neuropathic form of diabetic foot), cancer (radiation ulcers), and so on. Neurotrophic ulcer defects, as consequences of spinal cord injury and peripheral nerves, are difficult to conservative therapy and surgical correction. In the United States, every year more than 8-10 thousand new cases of complicated vertebral and spinal trauma are recorded, in Ukraine this figure is 2-3 thousand per year [3].

Despite the introduction of high-tech non-invasive neurosurgical techniques, the vast majority of patients with the consequences of traumatic injury to the spinal cord are disabled $[1,4]$.

The aim of the study is to improve the treatment results of patients with long-standing wound defects of trunk and extremities by using alternative methods.

\section{Materials and methods of research}

75 patients with neurotrophic disorders aged 19 to 76 years old, with an average age of 47.5 years, were treated from 2011 to 2017 at the clinical basis of the Department of Disaster Medicine, Military Medicine, Anesthesiology and Intensive Care of Zaporizhzhia State Medical University. Women - 27 (36\%), men - 48 (64\%). There were 25 $(33.3 \%)$ patients of the total number treated according to the new methodology using hyaluronic acid preparation, which has been developed in the clinic [2].

The patients were performed the following diagnostic measures: general clinical examination, angiological, neurological examination, clinical and laboratory diagnostics, microbiological monitoring of the wound contents, $\mathrm{CT}$, electroneuromyography, Doppler ultrasonography, photodocumentation.

The complex pathomorphological study of the skin biopsy material was performed by histological (staining with hematoxylin and eosin), histochemical (Van Gieson's stain), immunohistochemical (according to the standardized protocols [6]. Using monoclonal antibodies $\mathrm{Rb}$ a-Hu Collagen I, Clone RAHC11 and Rb a-Hu Collagen III, Clone RAHC33 (Imtec, Russian Federation) to collagen types I and III). For the morphometric study, the skin preparations were photographed in 5 visual fields by the digital camera
"Canon EOS 1000D" (Japan) in the microscope Axioplan 2 (Carl Zeiss, Germany) with the magnification x200 and analyzed using the software ImageJ [11]. For the morphometric measurement of the relative area occupied by immunopositive structures, a standard "threshold of sensitivity" (the Threshold tool) was set up in the filtered image $\mathrm{DAB}$ channel for automatic segmentation of the digital image into two main types of pixel points (black and white), followed by the calculation of the ratio of the number Black pixel points (immunopositive zones) to the total number of pixels in the image, expressed in $\%$. The statistical processing of the results was performed on a personal computer using the analysis package in the program Excel Microsoft Office 2013 and Statistica ${ }^{\circledR}$ for Windows 6.0 (StatSoft Inc., License number AXXR712D833214FAN5). Median (Me), lower and upper quartiles (Q1, Q3) were calculated.

\section{Results and discussion}

With neurotrophic ulcers (6 (8\%) of patients) with damage to peripheral nerve trunks, it was mandatory to conduct electroneuromyographic examinations with a neurosurgeon's inspection and the appointment of a special treatment. In 5 cases of trophic ulcers on the lower extremities, autografting was performed by a split skin graft, in one case of a wound defect on the forearm, they performed plasty with a rotation skin adipose flap on the axial blood supply.

In the $44(58.7 \%)$ patients, the decubital trophic defects III-IV degree in the spine (27 cases) area and the site of greater trochanter of femoral bones (21 cases) were diagnosed. The choice of the type of surgical intervention depends on the size of the defect.

In 12 patients there were 2 localizations simultaneously, in 4 patients - 3 localizations. In case of vertebral localization of neurotrophic ulcers, in 7 cases, plasty was used with one or two V-like skin and muscle rotation flaps; in 16 cases plasty was with skin adipose dicotyledonous pedicle flap; in 9 cases of neurotrophic ulcers in the site of greater trochanter plasty with rotation skin adipose dicotyledonous pedicle flap was performed. In other cases wound defects plasty was performed by the split autografting.

To prevent the development of seromas and hematomas in the early postoperative period, active drainages were installed for up to 5-7 days. Mandatory preoperative preparation included rational antibacterial therapy, taking into account the sensitivity of the sown flora, restoring electrolyte, water and protein balance. In all the patients, the primary healing of wound defects has been noted. Cases of rejection, marginal necrosis of flaps haven't been marked. In 3 cases subflapular seroma (up to $5 \mathrm{~cm}$ in diameter), which was successfully eliminated, occurred. In the remote period recurrences of neurotrophic ulcers have not been noted. 
In $25(33.3 \%)$ cases of neurotrophic ulcer defect on the heels and residual defects in the area of the sacrum, buttocks a redermalization course was prescribed for 2 to 6 weeks with a positive result (complete defect healing) in all the cases.

Clinical manifestations of neuropathy were absence of pain, immutability of skin integuments temperature and their normal color, intact pulsation in the dorsal arteries of the foot, the presence of hyperkeratosis on the sole, specific deformity of the fingers, feet and joints. Trophic ulcers were localized in the places of excessive pressure on the sole - the area of the heel, the heads of metatarsal bones, the lateral part of the foot. The electroneuromyography confirmed the diagnosis in all the cases, namely, the lack of electrical conductivity along the peripheral nerve endings of the leg.

The basis of the new method for the treatment of trophic ulcers in the lower extremities is using a combined preparation of hyaluronic acid with sodium salt of succinic acid [2].

We have used the preparation of hyaluronic acid with sodium salt of succinic acid by injecting $1.0 \mathrm{ml}$ of $1.5 \%$ solution intracutaneously around the ulcer defect once per week for 5-7 weeks. During the treatment, dynamic measurements of the trophic ulcer defect were performed.

All the patients were treated according to this method and they were discharged with a positive result, namely, the complete healing of the trophic ulcer defect.

The introduction of hyaluronic acid preparations into the extracellular matrix provides the site of the surgery with the additional amount of hyaluronic acid to optimize the performance of its biological functions in the skin, such as: the tissues' turgor and flexibility increases and the processes of elastogenesis, collagenogenesis and angiogenesis are stimulated. Sodium succinate (sodium salt of succinic acid) operates at the level of mitochondria - to activate the processes of cellular respiration, ATP synthesis and the structural proteins of the skin.

This treatment technique can be used not only at the conditions of in-patient department but at the out-patient setting too which significantly reduces the terms of treatment and patient's stay in the hospital.

Despite the fact that redermalization is the technique that requires special training, its further use does not require specific instruments, anesthetic support, or operating room.

Conducting weekly measurements of ulcer defect makes it possible to evaluate the results of treatment in the dynamics and be able to correct treatment, which does not require special tools either, except for centimeter tape or tracing paper.

Thus, the combination of the afore-mentioned positive influences has contributed to increase the efficiency of treatment, to accelerate the recovery of patients, reduce the number of complications and reduce the number of bed days.

In addition to the fact that the use of this method does not require special means and the attracting of the other profile specialists, it can be used in the outpatient mode for the treatment of prolonged existing trophic ulcers with vascular etiology in the complex with surgical methods of intervention.
Example. Patient L., 1982, the history of the disease No. 1199 was admitted to the Department of Thermal Injury and Reconstructive Surgery with the diagnosis: Consequences of severe spinal trauma. Vertebral fracture L1. Spinal cord contusion. Neurotrophic ulcer defects of the lumbar, sacrum, buttocks, both heels. Lower Paraplegia. Dysfunction of the pelvic organs in the form of retention.

Date of hospitalization: 25.01.2012.

Date of discharge: 07.03.2012.

On admission to the hospital the patient complained of the presence of wounds on the sacrum, buttocks, heels.

Anamnesis of illness: the patient considers himself to have been ill for six months, when he was injured falling from the height at the construction site. He has had the course of complex treatment in the neurosurgical department. In the postoperative period there were bedsores in the area of sacrum, heels. The patient was hospitalized to the department of thermal trauma for further treatment. Local examination of the sacrum area showed wound defect $10 \times 10 \mathrm{~cm}$ with straight edges and active granulations, in the area of both heels there is necrosis.

The patient received the course of antibacterial, infusion therapy, exercise therapy, massage, debridement of wound defects.

21.06.12 - operative intervention was performed closure of the neurotrophic wound defect of the sacral area with a rotation two-lobe fasciocutaneous flap. Sutures were removed on the $14^{\text {th }}$ day.

02.11 .11 - necrectomy of the marginal necrosis of the flap, secondary suturing, autoplasty.

18.11.11 - autoplasty of wound defects of heels.

13.12.11 - epicystostoma surgery.

19.01.12 - autoplasty of residual wound defects.

The patient is again hospitalized with residual wound defects in the area of the sacrum and heels and new neurotrophic defects in the buttocks.

After the course of antibacterial therapy, defects debridement

15.02.12 - autoplasty of wound defects was performed.

From 08.02.12 the course of injection $1.5 \%$ solution of hyaluronic acid started. In the dressing room, the patient's wound defect area was debrided with an antiseptic solution. The size of the defect was measured with the centimeter tape before the beginning of the therapy. Completely ready-to-use glass Luer-lock syringe filled beforehand and an additional needle with a solution of non-structured hyaluronic acid with succinate (concentration of hyaluronic acid $15 \mathrm{mg} / \mathrm{ml}$ ) was used. Indenting from the edge of the ulcer for $0.5 \mathrm{~cm}, 0.1-0.2 \mathrm{ml}$ solution is injected intracutaneously once by the tunnel method. Spacing between the injections is $0.5 \mathrm{~cm}$.

A sterile gauze bandage was applied on the wound defect. The procedure was repeated 2 times a week with the obligatory measurement of the wound defect and its photographing. The course of treatment was 2 weeks. After the treatment course, the complete epithelization of wound defects in the area of both heels and the buttocks was noted.

The clinical experience of using hyaluronic acid preparation has been scientifically substantiated by the studies 
performed in accordance with the program of joint scientific research of the Department of Medicine of Catastrophes, Military Medicine, Anesthesiology and Intensive Care, and the Institute of Clinical Pathology, ZSMU, dated Nov 20, 2015 on the base of the Institute of Clinical Pathology, ZSMU.

During the complex pathomorphologic examination of the skin biopsy material from the para-wound zone in $25(33.3 \%)$ patients with neurotrophic defects of the integumentary tissues, who had been treated by the method of using hyaluronic acid $1.5 \%$ with sodium succinate, it was found that the epidermis in these areas had a different morphology from the epidermis of healthy skin, which was represented by a stratified epithelium and consisted of several layers of keratinocytes. During maturation, these cells move from the proliferative state in the basal layer to the differentiated state, acquire stratified structure, lose their nuclei and form enucleated corneal layer.

In pathohistological examination of the skin biopsy material stained with hematoxylin and eosin, in this group of patients after the injections of hyaluronic acid preparation, the signs of healing wounds were revealed. In most cases, they were characterized by the formation of a thick, hyperproliferative epidermis containing mitotic active cells not only in the basal but also in the supra-basal layers, which according to some literature data is the result of activation and excessive expression of c-myc [9]. Furthermore, the other differences were found - the presence of hyperkeratosis (thick corneal layer) and parakeratosis (the presence of nuclei in the corneal layer), which can give evidence of the incomplete differentiation of keratinocytes and often characterizes the epidermis of chronic ulcers [7]. It is known that induction of c-myc and suppression of $\mathrm{K} 6 / \mathrm{K} 16$ can lead to inhibition of keratinocytes migration in human skin, which contributes to the incomplete activation of keratinocytes and possibly the development of chronic wounds $[8,9]$. In some cases, the restricted areas of granulation tissue formation were identified and the areas of pseudoepytheliomatous hyperplasia, that is often revealed in chronic defects' edges and caused by chronic injury of the damaged areas.

At the histochemical studies of the skin fragments in this group of patients, stained according to Van Gieson's method, the areas of sclerosed dermis with intensely developed collagen framework were revealed as unsystematically arranged thin and thick bundles of collagen fibers and inflammatory cell infiltration between them. In some cases, the normal structure of the dermis with a neat and orderly network of collagen was detected, which was covered with a thin layer of epidermis. It is known that the initial phase of wound healing is characterized by the release of IL-1 and TNFa by keratinocytes that acting autocrinely, increase the migration and proliferation of keratinocytes, activate adjacent fibroblasts and increase the secretion of FGF (fibroblast growth factor), which in turn promotes the migration of fibroblasts and the accumulation of ECM components, primarily collagens [12]. The other important signaling molecule produced by both keratinocytes and fibroblasts is TGF- $\beta$. Its expression induces the formation of granulation tissue, reepithelization and tissue reconstruction [5].
In the parallel immunohistochemical examination of these skin fragments, using monoclonal antibodies to collagen types I and III in most cases its marked expression was revealed with considerable accumulation in the form of wavy pale and intensely colored single and collected in fascicles, sometimes interwoven with each other fibrillary structures in all the layers of the dermis. During photodigital skin fragments morphometry in patients with neurotrophic ulcers it was determined that the relative area of collagen type I deposition is $28.15(24.35 ; 35.24) \%$ and collagen type III - 23.01 (20.94; 25.95) \%.

Thus, it was determined that in the dermal structures of most patients in this group there was a denser accumulation of collagen type I than collagen type III, that according to the findings of other studies may be the result of an imbalance between the processes of synthesis and degradation of proteins of extracellular matrix and leads to the pathological scarring $[10,14]$. According to some studies, it has been established that chronic inflammatory infiltration in the zones of skin damage is accompanied by activation of leukocytes, cytokines and matrix metalloproteinases, which support the inflammatory reaction, stimulate pathologic production of collagen by fibroblasts, their proliferation and pathological fibrosis, as well as lipodermatosclerosis [10].

In the complex microscopic examination of skin tissue sections stained with hematoxylin and eosin and according to Van Gieson's method in the control group of patients (20 ones with wound defects of the integumentary tissues of the trunk and extremities without damage to the nervous structures) the areas with intensive development of the dermal collagen framework covered with a thin layer of the epidermis, that contained mitotic active keratinocytes in the supra-basal layers, often with flattening of the dermally-epidermal junction. Fibroblast clusters and a focal lymphocytic infiltration were revealed among collagen bundles. In the analysis of digital images of skin samples with immune positive zones in this group of patients it was also observed an intense accumulation of collagens types I and III as pale and dark brown fibrous structures of thin single and organized into bundles fibrils in all dermal layers. In this case, the relative area of accumulation of collagen type I was lower than in the previous group and amounted to $19.01(14.80 ; 22.73) \%$ and collagen type III $-26.67(25.11 ; 33.01) \%$. This way it was found that in the dermis of the most patients in this group a significant accumulation of collagen type III was observed, which usually occurs at the early stages of regeneration than collagen type I that according to the data of the other studies is revealed in immature connective tissue [13] and is explained by the early stages of surgical interventions and the intake of skin biopsy material after tissue damage in this group of patients.

\section{Conclusions:}

1. The choice of the method of corrective intervention and the closure of the defect depended on the size, depth of the wound and the functional characteristics of the damaged site.

2. The new method of treatment of neurotrophic ulcers of the lower extremities using hyaluronic acid preparation 
with sodium succinate enhances the prospects for treatment of patients with integumentary tissues defects.

3. Pathomorphological examination of skin fragments in patients with neurotrophic ulcers revealed signs of healing with hyperproliferative processes in the epidermis, hyperkeratosis, parakeratosis, and the excessive accumulation of collagen type I which characterizes pathological scarring and is often determined in the epidermis in chronic ulcers.

4. Differential approach to the selection of the method of closing wound surfaces associated with damage to the central and peripheral nervous systems makes it possible to achieve positive results in $98.1 \%$ of cases.

\section{References}

[1] Pedachenko, Ye. H., Polishchuk, M. Ye., Huk, A., \& Nykyforova, A. M. (2017) Neirokhirurhiia v Ukraini: vid zizdu do zizdu [Neurosurgery in Ukraine: from the congress to the congress]. Abstracts of Papers of the VI Congress of Neurosurgeons of Ukraine. Kharkiv. [in Ukrainian].

[2] Ponomarenko, O. V., \& Virskyi, M. V. (patentee) (2011) Patent. 65158 Ukraina, MPK A61K 31/00. Sposib likuvannia likuvannia trofichnykh vyrazok nyzhnikh kintsivok [Patent. 65158 Ukraine, IPC A61K 31/00. Method of treatment of treatment of trophic ulcers of the lower extremities]. Biuleten, 22. [in Ukrainian]

[3] Piedachenko, Ye. H., Ipatov, A. V., \& Tarasenko, O. M. (2012) Statystychnyi analiz invalidnosti pry travmi khrebta ta spynnoho mozku [Statistical analysis of disability in the spine and spinal cord injury] Zaporozhye medical journal, 6(75), 21-23. [in Ukrainian].

[4] Yaminskyi, Yu. Ya. (2017) Rekonstruktyvno - vidnovne likuvannia khvorykh z naslidkamy travmatychnoho ushkodzhennia spynnoho mozku Restoration Treatment of Patients with Consequences of Traumatic Damage of the Spinal Cord]. Abstracts of Papers of the VI Congress of Neurosurgeons of Ukraine. Kharkiv. [in Ukrainian]

[5] Morimoto, N., Yoshimura, K., Niimi, M., Ito, T., Tada, H., Teramukai, S. et al. (2012) An exploratory clinical trial for combination wound therapy with a novel medical matrix and fibroblast growth factor in patients with chronic skin ulcers: A study protocol. Am. J. Transl. Res., 4, 52-59.

[6] Dabbs, D. J. (2010). Diagnostic Immunohistochemistry. Philadelphia: Saunders/Elsevier.

[7] Usui, M. L., Mansbridge, J. N., Carter, W. G., Fujita, M., \& Olerud, J. E. (2008) Keratinocyte migration, proliferation, and differentiation in chronic ulcers from patients with diabetes and normal wounds. J Histochem Cytochem, 56, 687-696. doi: 10.1369/jhc.2008.951194.

[8] Lan, L., Hayes, C. S., Laury-Kleintop, L., \& Gilmour, S. K. (2005) Suprabasal induction of ornithine decarboxylase in adult mouse skin is sufficient to activate keratinocytes. J Invest Dermatol, 124(3), 602-614 doi: 10.1111/j.0022-202X.2005.23620.x.

[9] Stojadinovic, O., Brem, H., Vouthounis, C., Lee, B., Fallon, J, Stallcup, M., et al. (2005) Molecular pathogenesis of chronic wounds: the role of beta-catenin and c-myc in the inhibition of epithelialization and wound healing. Am J Pathol., 167(1), 59-69.

[10] Puri, V., Venkateshwaran, N., \& Khare, N. (2012) Trophic ulcers Practical management guidelines. Indian J Plast Surg, 45(5), 340-351. doi: 10.4103/0970-0358.101317

[11] Rasband, W. S., \& Image, J. (1997) National Institutes of Health. Bethesda, Maryland. Retrieved from USA-http://imagej.nih.gov/ij/, 1997-2016.

[12] Sogabe, Y., Abe, M., Yokoyama, Y., \& Ishikawa, O. (2006) Basic fibroblast growth factor stimulates human keratinocyte motility by Rac activation. Wound Repair Regen, 14(4), 457-462. doi: 10.1111/j.17436109.2006.00143.x

[13] Shi, H. X. Lin, C., Lin, B. B., Wang, Z G., Zhang, H. Y., Wu, F. Z, et al. (2013) The Anti-Scar Effects of Basic Fibroblast Growth Factor on the Wound Repair In Vitro and In Vivo. PLoS One. 8(4), e59966. doi 10.1371/journal.pone.0059966.

[14] Xue, M., \& Jackson, Ch. J. (2015) Extracellular Matrix Reorganization During Wound Healing and Its Impacton Abnormal Scarring. Advances in Wound Care, 4(3). 119-136. doi: 10.1089/wound.2013.0485.

\section{Information about the authors:}

Ponomarenko E. V., MD, PhD, Associate Professor

of the Department of Medicine of Catastrophes, Military Medicine, Anesthesiology and Intensive Care, Zaporizhzhia State Medical

University, Head of the Regional Center of Thermal Injuries

and Plastic Surgery, Ukraine.
Kovalenko I. S., MD, PhD, Assistant of the Department of Pathological Anatomy and Forensic Medicine, Zaporizhzhia State Medical University, Ukraine.

\section{Відомості про авторів:}

Пономаренко О. В., канА. меА. наук, Аоцент каф. медицини катастроф, військової медицини, анестезіології та інтенсивної терапії, Запорізький Аержавний медичний університет, зав. обласного центру термічної травми та пластичної хірургії, Україна.

Коваленко І. С., канА. меА. наук, асистент каф. патологічної анатомії і судової медицини, Запорізький Аержавний меАичний університет. Україна.

\section{Сведения об авторах:}

Пономаренко Е. В., канд. меА. наук, Аоцент каф. медицины катастроф, военной меАицины, анестезиологии и интенсивной терапии, Запорожский государственный медицинский университет. Украина, зав. областным центром термической травмы и пластической хирургии, Украина.

Коваленко И. С., канА. меА. наук, ассистент каф. патологической анатомии и судебной медицины, Запорожский государственный медицинский университет, Украина.

Конфлікт інтересів: віАсутній

Conflicts of Interest: authors have no conflict of interest to declare.

Надійшло до редакції / Received: 01.06.2017

Після Аоопрацювання / Revised: 12.06.2017

Прийнято Ао Аруку / Accepted: 13.06.2017 